Journal of Social Sciences (COES\&RJ-JSS)

ISSN (E): 2305-9249 ISSN (P): 2305-9494

Publisher: Centre of Excellence for Scientific \& Research Journalism, COES\&RJ LLC

Online Publication Date: $1^{\text {st }}$ July 2017

Online Issue: Volume 6, Number 3, July 2017

https://doi.org/10.25255/jss.2017.6.3.666.681

\title{
Managing Culliculum 2013 credit semester management system at National Senior High School Sidoarjo region (multi sites at Smani, Sman 3 and Sman 1 Krian Sidoarjo)
}

\author{
Musta'in, Bambang Budi Wiyono, Imron Arifin, Kusmintardjo \\ State University of Malang, Malang, East Java, Indonesia
}

\begin{abstract}
:
This research was aimed at finding out how Credit Semester Management System of the 2013 High School Curriculum was implemented. This research focused on three sites namely State High School \# 1 Sidoarjo, State High School \# 3 Sidoarjo, and State High School \# 3 Krian, East Java, Indonesia. This research employed the multicases research design. The data was collected using indept interview, participatory observation, and document analysis. The data was analized using individual cases and or crosscases analyses. This research found out that: (1) The three schools planned the credit semester similarly, students were to choose their own fields of learning; (2) The three schools had similar organizing system. The differences falled on the total of Academic Guider addition; (3) The three schools Actuated the Credit Semester System Management similarly, (4) The three schools conducted supervision and evaluation similarly. The three schools conducted the graduation for students finishing their learning tasks in 260 learning hours and reaching Achievement Semester Indext of at least 2,66; and obtained good score in attitude; and passed for the school examination.
\end{abstract}

\section{Key words:}

Managing 2013 High School Curriculum, Credit Semester Management System, Senior High School (SMA)

\section{Citation:}

Musta'in; Wiyono, Bambang Budi; Arifin, Imron; Kusmintardjo (2017); Managing Culliculum 2013 credit semester management system at National Senior High School Sidoarjo region (multi sites at Smani, Sman 3 and Sman 1 Krian Sidoarjo); Journal of Social Sciences (COES\&RJ-JSS), Vol.6, No.3, pp:666-681; https://doi.org/10.25255/jss.2017.6.3.666.681. 


\section{Introduction}

All public junior and senior high schools as well as the vocational high schools had to be accreditated and obtained A level of the National Institution Acreditation standard to conduct the Credit Semester System (Indonesian Republic Ministry decree Number 81A, 2013). The implementation of Credit Semester System (SCS) at junior and senior high school was a learning inovation using the package system. Students may graduate faster depending on their talents and interest. This accommodates the students' different potentials and dynamics (BSNP, 2010).

As a new inovation, it needs an extra effort to overcome the problems to implement it. Budiman (2013) says that "Many things have to be considerated carefully, if implement credit semester system at school, moreover with 2013 curriculum issued". The effectiveness to implement credit semester system depends on many things including the teachers and aministrators' competencies (inspector, head master and teachers) regarding to needs of the institution, students readiness, curriculum structure arrangement, learning tasks, learning design, assessment, school management, field of study and guidance, and graduation competence standard.

It was observed that at some schools in East Java, there were many problems related to school management. In Sidoarjo region for instance, since SCS was issued in 2013, through the head of Sidoarjo region's decision, Number: 188/410/404.1.3.2/2013 Year 2012, the three superior schools were chosen. These three high schools were the socalled SMA Negeri 1 Sidoarjo, SMA Negeri 3 Sidoarjo, and SMA Negeri 1 Krian Sidoarjo. These three schools experienced problems in the teacher readiness, administrator technical competencies, and the students who apply SCS program, learning schedule arrangement, (learning activity in the classroom, extracurricular activity, stuctural activity, and independent activity), the way to state and decide minimal learning task, learning service with "on and off " or regular program, so this problems have to have solution in order to fulfil the criterion based on the rule.

Since the 2013 curriculum was implemented at some school models, all of the school activities must be similar to the aim of this curriculum. One of them was the students' task management (Based on the rule of Education and Cultural Minister of Indonesia Republik Number 81A Year 2013 about the 2013 Curriculum Implementation). The Ministerial rule of Education and Culture of Indonesia Republic Number 69 Year 2013 stated that the high schools Curriculum Task was organized into oblight subject contents groupping into A and B, students' subject interests, as well as the school education characteristics.

\section{Method}

This research employed the descriptive qualitative multy sites approach. It was chosen because of the nature to analize two or more subjects, place or data server lineary. Multy site study examines certain subjects and compares the similarity and the discrepancy of the sites. This research was aimed to find out the the phenomenon or social symptom comprehensively and contextually to illustrate empirical practice of Semester Credit System Management to implement the 2013 Curriculum of Senior High School in Sidoarjo region.

Based on the approach and research design, the instrument for collecting data was the researcher himself. The Researcher attendance in field was as one of a succesfull 
benchmark to cmprehend of the research case. Researcher has to play role as instrument key to examine the case related with research objects especially in collecting data. Wiyono (2007) says that a researcher has to play role proportional as observer and as the group members of the research target. The research locations was the Regional Department of Education of Sidoarjo, East Java, Indonesia comprising three high schoos which were the so-called SMAN 1 Sidoarjo, SMAN 3 Sidoarjo, and SMAN 1 Krian Sidoarjo. The site stated was based on geography positions and the similarity condition of the schools, school types, status, and accreditation A status which implement semester credit system. All of the three schools were chosen by Regional Department of Education, Sidoarjo, East Java.

Data resources in this research were distinguished into two forms, there were: (1) human data resourses, inlude headmaster, curriculum and academic affair, student affair, school facility affair, and public relation and teacher and administrator affair; (2) non-human data resources include: research documentation from all activity along the research at SMA Negeri 1, SMA Negeri 3, and SMA Negeri 1 Krian Sidoarjo. The informan in this case, collecting the data after having observation, and interview or consulting with point of view at the schools.

Recording of the main data resources were done through interview, and observation, they are as the association of viewing activity, listening, and questioning. Interview is done by researcher as open interview, it means that all the informen comprehend about the point and the interview aims. Others, researcher adds with relevant data for instance: about place, and events along the observation directly related with semester credit system management in the sites.

The data in this research was collected through three technics, they were observation, interview, and documentation. Observation technic was used when researcher attended in the research spots and researcher avoided not to disturb learning process at the so-called SMA Negeri 1, SMA Negeri 3 and SMA Negeri 1 Krian, Sidoarjo. Interview technic was done by construct and unconstruct face to face by asking questions to the informen. Documentation technic was taken through writing or document resources in the research spots, like Guidance SCC Book, Curriculum 2013, School Planning Progress, School Budget Planning, Implementation semester credit system report, phograph of the school events and videos related with SCC implementation at SMA Negeri 1, SMA Negeri 3, and SMA Negeri 1 Krian Sidoarjo. Multysite data analysis in this research was done into two steps, they are: (1) individual cases; and (2) cross-cases analysis. Independent data site analysis was analysis data at each subject-object (SMAN 1, SMAN 3, and SMAN 1 Krian, Sidoarjo). Data analysis across sites, it was for comparing the finding from every cases, and also for unify between cases simultanioustely. First of all, based on the findings from each individual site (SMAN 1 Sidoarjo), arranged category and theme, and analized inductive and conceptually, and explained narratively which was composed into certain propositions and then developed into substansive 1 theory.

The propositions and substantive 1 theory, afterwards was analyzed through comparing with prepositions and substantive 2 theory of the individual 2 findings site (SMAN 3 Sidoarjo), to seek unique and discrepancy characteristic of each sites as theory conception based on discrepancy. After that, analysis across 1 and 2 with the site 3 (SMAN 1 Krian Sidoarjo) with the same technich like at case 1 and 2 . At the last point, it was for 
arranging systematic conception based on data analysis and data interpretation theory in narrative form propositions across site, after that, it was be materials for ddeveloping finding theory substantively.

Those data analysis occurred simultanioustly and it's done equally with collecting data process with the steps as follow: data collecting, reducing data, display data, and saving data or verifying data or conclusion drawing. Data analysis in this research is done when on going process and cyclical in order to get finding and overcome the research problems until research report arranged. Criterion validity of the research data was used including: credibility, transferability, dependability, and confirmability. For completing credibility aspects of this research, researcher uses five technics to inspect, they were: exertion observation, triangulation, and enough referential. The effort for completing dependenbility concept, reseracher is often attend in the field or spot, anad found a lot of informen and also checking of the data presented. For completing transferability aspect, researcher had effort to present the research result completely and detail so all of the site is able to comprehend better, if it's necesarry. For completing confirmability, researcher is doing the same as dependence concept through data audit process.

\section{Findings and Discussion}

Planning

It was found out that Focus I (Planning) was the activities to make decision for applying the semester credit system in order to reach the aim with the components: (1) a number of activity that had been ditermined before, (2) there was processes, (3) there was the product that was desired to reach, and (4) concerns with the next period in the certain time (Usman, 2013: 77).

The application of the semester credit system in all state high shools in Sidoarjo including the three high schools the so-called SMAN 1, SMAN 3 and SMAN 1 Krian, Sidoarjo region was based on a number of rules as follow: (a) The law of Indonesia Republic Number 20 Year 2003 about National Education System; Governor Rule Number 19 Year 2005 about National Education Standard; (b) Guidance of Semester Credit System of National Education Standard Board April 2010; (c) The rule of Education Minister of Indonesia Republic Number 81A Year 2013 about Curriculum 2013 Implementation; The Rule of Education and Cultural Indonesia Republic Number 158 Year 2014 about SCS; (d) The Rule of Sidoarjo region head Number 188/410/404.1.3.2/2013 about appointment of the school Implement SCS, (d) The Rule of Sidoarjo region head Number 63 Year 2011 about Education Standar of Local Task Reading and Writing of Al Quran and (e) The Rule of Sidoarjo distric head as converting of the Rule of Sidoarjo region head Number 21 Year 2015 about Guidance of Implementing for the New Students Enrolling of Junior and Senior High School SCS Curriculum 2013 in surrounding Sidoarjo region.

Managing Primarily

In the rule of Education Minister and Cultural Indonesia Republic Number 81A Year 2013 about Curriculum 2013 Implementation was mentioned that the managing primarily of SCS enclose: (a) students determine their learning tasks by themselves, and the subjects that they would learn in every semester based on their ability, talent and their interest; (b) students who had high ability and vilition were able to shorten their learning duration and had to master their learning; (c) students was motivated to empower themselves by 
induvidual learning; (d) students were able to ditermine and managing their learning strategy flexiblely; (e) students had a chance to chose group of interest subject, across interest, intensifying interest and also the subject that suitable with their potency; (f) students were able to move to other schools but the school has to implement SCS Curriculum 2013.and doing transfer credit; (g) school provides education resources more suitable technically and administrative; (h) learning schedule was able to fullfil the students development include knowledge, attitude and skill; (i) teacher facilitates the academic students need based on their ability, talent and interest; (j) school which implemented the semester credit system had formal certificate from National Accreditation Institution with A score.

Procedure and Mechanism

The Procedure and mechanism for implementing semester credit system at all the schools of the so-called SMAN 1, SMAN 3, and SMAN 1 Krian Sidoarjo region, included: (a) proposing permition to The Department of education in Sidoarjo region; (b) implementing the semester credit system by announcing to internal schools covering teachers and school committee and students parents; (c) preparing the implementation of semester credit system in School Planning Program and School Curriculum document and had to obtain the agreement from Education Department Sidoarjo region; (d) having written permission from the department of education in Sidoarjo region and then announcing to the society for New Students Enrollment. Completing with the activities, were as follow: (a) joining workshop on semester credit system which was managed by the development sector of Education Department in Sidoarjo region; (b) carrying out workshop about semester credit system at school levels for arranging implemtating instrument of the three schools; and (c) having announce to the students, students parents through brochure for the society arround Education Depatment of Sidoarjo region.

Technical Preparation

Technical preparation for implementing the semester credit system at the school SMAN 1, SMAN 3, and SMAN 1 Krian Sidoarjo region, among others were : (a) the schools preparing administration document, teachers, activity program; (b) providing curriculum documents consisting of the curriculum stucture and learning task declared as semester credit system, core competency-competency base of the subject, sillabus and Subject Planning which was arranged by series of learning subjects; (c) preparing teachers, as subject teachers, Academic Guidance, who have been trainned about semester credit system; (d) arranging activity program at the school program which accomodate new students enrollment, consulting to academic guidance and concelor and On or Off learning schedule; (e) applying new student enrollment objectively, transparent and acountable coordinated by Education Department Sidoarjo region; (f) procedure and mechanism new students enrollment is determined by the head region of Sidoarjo through Education Department Sidoarjo region; (g) reporting capacity of students based on the classroom occupancy standard and (h) the number of students capacity in each interest subject had to be suitable with the number of teachers. Interest subjects were consisted of Mathematics and Science, Social subject, and language and cultural subject.

Curriculum Structure and Learning Task 
Of the three schools SMAN 1, SMAN 3, and SMAN 1 Krian Sidoarjo region included: (a) learning task had to be done by the studets at least 133 SCS, it coud be done the fastest for 2 years or 4 semesters and the latest for 5 years or 10 semesters; (b) learning task composition consists of group A (mandatory), B (mandatory), and one of group C (interest subject), and also accross interest subject and/or comprehensive interest; (c) learning subject was arranged by maximal for 4 series in order to accomodate the students who have speed learning of high level so they were able to finish their study in 2 years or 4 semesters.

Local Load Subject

Local load subject of the three schools SMAN 1, SMAN 3, and SMAN 1 Krian Sidoarjo region included: (a) local load subject was as materials of study at school that consisted of load and learning proces of potency and local unique to form the understanding of the students about district potencial; (b) kind of local load subjects could be formed as: local language, English, arts, vocational and handycraft, tradition, and knowledge about nature surrounding characteristics, and the things that regarding to develop as the local potencial; (c) development of local load subject was able to be done by the school independently and/or by local authoroty; (d) local load subject was able to be applied through certain subjects, integrated subjects, and/or through extracurricular activity; (e) local load subject which was developed by local authority of Sidaorjo region for SMA is reading and writing Al Qur'an; (f) local load subject could be integrated in art and cultural subject, vocational and enterpreneurship, and/or Sport and healt; and (g) extracurricular activity which was developed by the school based on the potencial it's school potencial.

Extracurricular Activity

Based on the research in the three schools MAN 1, SMAN 3, and SMAN 1 Krian Sidoarjo region was found that extracurricular activity: (a) extracurricular was done by the students out of the learning activity in the period of curriculum standard as extention activity and guided by school, it was focused to develop students personality, talent, interest, and the students ability out of their interest which was developed by school; (b) mandatory extracurricular was an extracurricular program had to be followed by all students, except for certain students with limited condition so they were not be able to joint this activity; (c) choice extracurricular were Student Organization, School Health Effort, Youth Red Cross. Moreover, the students activities could be undergone into other developed activities due to the subject matters such as, football or voley ball; (d) Students were compulsarily to join the scout and at least one of the extra curriculair programs provided; (e) The Extra curriculair programs were carried out after school.

On and Off Schedule

The result of the research on three schools (SMAN 1, SMAN 3, and SMAN 1 Krian, Sidoarjo Region) found that : (a) On and Off Schedule was a choice of learning contant and subjects selected by the students based on their needs, mood and mode of learning. On and Off Schedule was considered as a means to take the subjects and learning contents in each semester to carry out semester credit system; (b) Senior High School prepared the on and off schedule for 6 semesters as the resoures of selecting subjects taken and learning contents. (c) On and off schedule was arranged to make learning hours well distributed in the first and second semesters. (d) arranging on and off schedule should have considered the students learning contents in every semester. (e) The Highest Speed Learning Students could take more both learning content and more subjects so the schedule could be moved 
to former semester. (f) on the semester credit system, the Senior High Schools facilitated On and Off Schedule for those who could finish their study in two years or 4 Semester.

Academic Advisor

The result of the research on the three schools (SMAN 1, SMAN 3, and SMAN 1 Krian Kabupaten Sidoarjo) showed that Academic Advisor were the teachers whose job were to guide the students Achievement Progress through the school years. They guide not more than 20 students. The Academic advisors had to (a) observe and analyse toward the data, needs, their competence, and achievements got from Counselor teacher. (BK) and also gave constructive recommendation during learning and gave special help to make students gain their dreams maximally; (b) to guide students when they filled Learning Plan card. (c) managing assessment result of noble value and personal competence from Religion Education and Civic teachers and other subjects; (d) interlace communication and collaboration with student's parents, councelor and other subjects; and (e) Academic Adviser served academic consult at least six times in a semester, it's proved by consulting service journal.

Guidance and Counceling

At SMAN 1, SMAN 3, and SMAN 1 Krian, Sidoarjo region were found that the teachers of guidance and counceling were professional. They guided and gave counsulting to their students in order to be capable developing their potency and self reliant and self decision and self choice to realize their better life. In semester credit system implementation, a councelor guides at least 150 students in a semester: (a) observing, collecting, and recording data, as well as potency analysis, student's need, interest, and student's achievement; (b) monitoring, detecting, and giving constructive recomendation, so that students reach their self development through self development activity included specific purpose services; (c) guiding students on grouping consultation based on service schedule, as well as individual service based on the student's need; (d) reporting assessment result of personal development activity every semester; and interlace communication and collaboration with the students' parent, Academic Guide, and subjects teacher. Guidance and counceling activity can be applied in the classroom with the schedule equal with 2 lerning hours or it can be applied out of the classroom.

Teaching Task Management of teacher

This aspect seemed difficult at semester credit system management, because some teachers had not been recognized in Education Basic Data was at the three school SMAN 1, SMAN 3, and SMAN 1 Krian Sidoarjo region manage them according to: (a) teaching task 24 learning hours minimal, it was shown by teaching and learning schedule and head master mandate; (b) a short semester signing task could be counted as teaching and learning task; (c) the school could be encouraged development of teacher competency gradually so that they have skill, integrity, and change their mind to new education paradigm based on semester credit system characteristics; and (d) teaching and learning tasks of teacher was able to inform before filling Study Planning Cards gradually.

Information Management System

At SMAN 1, SMAN 3, and SMAN 1 Krian, Sidoarjo region had information management system as follow: (a) in SCS implementation the schools arranging and managing information management system perfectly, this system was for increasing faster information system, easier, openened, and accountable; (b) developing and completing 
information system which facilitated by government; (c) academic information system servicing the school stakeholder, among others were: (c.1) teacher, for documenting, managing, and verifying the students competency assessment of their affective, knowledge, and skill; (c.2) Academic Adviser, controlling the increasing of students' competency; (c.3) headmaster and vice headmaster of academia: controlling assessment of all subjects data; (c.4) parents and students, comprehend students' achievement of the subjects they learned; (c.5) Educational institution of Sidoarjo region, controlling semester credit system implementation servicing to the society; (d) Semester credit system schools provided special person to manage academic information system; and (e) Information system was developed and completed gradualy as information transparency to the public relation, appropriate with the Constitution of Indonesia Republic Number 14 year 2008.

Handoko (2012) mentioned that the twelveth steps above is able to: (a) give guideline to consider the aim and the best procedure to reach the goal; (b) organization was able to get resources to gain the goal; (c) the organization members were able to dothe activity consistently based on the procedure chosen; as well as (d) the progress was monitored and measured, so corrective step can be done if the school progress unsatisfactory.

Focus II, organization was collaboration process between two or more person to reach a certain goal effectivelly and efficiently (Usman, 2013: 171). Organizing is as collective activity, personal task, authority delegation to implement some certain activity which identified, so it could support the manager to consider coordination, capability, and relationship would be developed in organization. Organizing not only dealing with task distribution, but also with the conten, system, and process as well as educational system components. So, organizing system in SCS implementation at the three schools, there was no changed or the same as with the schools which implementing pakge system Curriculum 2013, but differentiate just on adding resources of Academic Adviser, in organization structure semester credit system was intended for reaching effort which coordinated by applying task and authority relationship as well as task distribution, it was able to applied responsibility and optimally. In organization system, Academic Adviser did not belong to structural position, but it was more point at academic adjusment. The semester credit system of the 2013 Curriculum implementation organiganization, at SMA Negeri Sidoarjo region generaly are: (a) headmaster, as learning leader; (b) vice headmaster curriculum affairs; (c) vice headmaster student affairs; (d) vice headmaster school facility affairs; and (e) vice headmaster of society relationship affairs, adding with Academic Adviser.

Focus III, there were seven components in semester credit system of the 2013 Curriculum implementation management of the three senior high schools at Sidoarjo region, among others are: term of implementation, new student orientation periode, learning subjects selection mechanism, task selection of student learning, field of interest, across field of interest, comprehand field of interest, and class movement.

Term of implementation

The semester credit system of the 2013 Curriculum implementation at SMAN 1, SMAN 3, and SMAN 1 Krian Sidoarjo region were started on March until May 2013. Since early semester credit semester implementation until now there had been many revision, from the rules in spite of implementation technic of each schools. So, there were common 
things when the cases increasing continuoustly, because it was a new wisdom with new method to implement it.

New Student Orientation Period

The implementation of new student orientation period at the three schools, SMAN 1, SMAN 3, and SMAN 1 Krian Sidoarjo region having goals: (a) potency and general test to map out the student potency, in this step was prioritized at the students' good attitude and personality; (b) introducing to school surrounding; (c) learning model and assessment socialization; (d) Curriculum of Semester Credit System socialization.

Learning Subject and Learning Task Selection Mechanism

At the three school which implement semester credit system of the 2013 Curriculum of SMAN 1, SMAN 3, and SMAN 1 Krian Sidoarjo region were organized as follow: (a) learning task and learning subjects selection is applied by filling Study Planning Card before semester learning start; (b) taking learning task has to accompany by Academic Adviser; and (c) criterion is used to determine student learning task as follow: (c.1) in semester 1 student took learning task based on the learning achievement on the school before or based on the new student selection test tant consists of paper test and psychology test; (c.2) next semester was determined by Achievement Index; (c.3) student had to finish all of the subjects in curriculum structure; and (c.4) the school was able to arrange learning subjecs completely by using on and off technic, it means a subject could be learned in certain semester.

Majoring/ selecting group field of the study

Based on the results of the research in the three schools SMAN 1, SMAN 3, and SMAN 1 Krian, Sidoarjo region it was found out that the majors / concentrations of the field of study were: (a) the study that was conducted at the beginning of semester 1; (b) the criteria of the majoring was considered on the basis of the student's interests, the results of academic potential test (TPA) and the result of academic test of the four subjects: Indonesian language, English, Mathematics, Science and Social Studies; (c) the other considerations of the majoring was based on the result of questionairs that were given and responded by the students and approved by students' parent; (d) recommendation or note from previous school (SMP / MTs); (e) and for those who had not decided their major as doubt or hesitation, they were advised to take an interview or consultation with school counsellors and the results must be approved by parent.

So, this was clearly understandable that: (a) the majoring (selecting subjects or groups field of study) was done based on students' interests, talents and abilities during learning at SMA or Senior High School. In addition, the majoring is also done on the basis of the students' need in continuing to higher level education or college; (b) the other, eventhough students had decided their own major as main priority to study, they still have an opportunity to take the other subjects from the other subjects group. This opportunity is given, probably, learners are furious to take subjects which they really want to study but the subjects are not available in their main major. (c) learners who had better academic achievements were able to take a valuable chance for learning more and deeper as enrichment in thier field of study or major. This program was carried out in collaboration with universities that was facilitated and coordinated by Education department.

Taking cross major or interest. 
Interdisciplinary subjects could be defined that learners are able to learn or study the subjects outside the their own selected subject groups or major. For example, for learners who had decided to choose subjects in Social group, they are still allowed to take and learn subjects from Mathematics and Science Group, or Language Group. However, they were only permitted to learn 14 credits covering 6 credits in 2 subjects which can be completed in semester 1 and 8 credits in 1 or 2 subjects that had to be accomplished in semester 2. Indetails, the condition of the cross major both the grade X and XI and the subjects they were learning had to be made the same. This must be happened dealing with the optimization of learning outcomes, availability of teachers, classrooms, and the number of students.

Deepening of major or Interest

A deepening of interest was only provided for learners who had intention to pursue higher education or college. However, the program in the deepening of students' interest or major had not been fully regulated in the system of implementation of Credit Semester Management System (SKS) at SMA in detail and specific. Consequently, upto now, SKS providers school can not run the program properly and optimally.

Moving Class

In the three schools of SMA Negeri Sidoarjo (SMAN 1, SMAN 3, and SMAN 1 Krian Kabupaten Sidoarjo) moving class activities were carried out: (a) to improve the quality of the learning process, improving the effectiveness and efficiency of learning time, improving students' and teachers' discipline, improving teachers' competence in various methods and media to meet the need of students' life; (b) in the moving class, the classroom was set just for a particular subject and students will move to another classroom for each subject. Thus, the classroom will work like a laboratory. Through moving classes, students may learn to vary from one class to another according to the field of study they are studying; (c) the management of the moving class must strongly consider to the learners in order to be more focused on the subject they were learning, to create comfortable classroom atmosphere, and to keep more condusive students - teachers interaction. For teachers, they should have been much more easier in preparing learning, more creative and innovative in designing the classroom, freer in using various media, more efficient in spending teaching time, and simpler to manage the classroom atmosphere.

Actuating (implementation). According to Hoy and Miskel (2005: 52), Actuating was the implementation of what had already planned in the management. The function of management covers leadership, motivation, communication, and the others that enable to influence the implementation of management to reach the goals of an organization. Dealing with implementation of credit semester management system (SKS) in the three schools (at SMAN 1, SMAN 3, and SMAN 1 Krian Kabupaten Sidoarjo), the crucial point in the deepening interest program (majoring) was evaluation, perfect components needed but still unavailable.

Focus IV, supervision and evaluation in the credit semester management system (SKS) 2013 curriculum at SMA Negeri Sidoarjo (SMAN 1, SMAN 3, and SMAN 1 Krian) covers 7 components. They were assessment, the threshold of learning mastery, grade promotion criterion, determination of achievement index (IP), remedial and short semester, graduation, and student's mutation 
Assessment

The assessment in the implementation of the SKS system in all three schools (in SMAN 1, SMAN 3, and SMAN 1 Krian Kabupaten Sidoarjo) was done in graded. First, it was initiated by teachers as educators, educators unit and government. All of these were conducted to aim at maximizing the learners' learning outcomes at school level, regional level and national levels in which allof them should be done in graded but still interconnected. Beginning from the completeness of learning outcomes, the competence of graduates in school exam (UAS), national exam (UN) and so on.

It was clear and understandable that the assessment in semester test of credit semester management system (sks) at SMA was aiming to: (a) collect and proceed information in order to know the achievement of learners' (outcomes) in attitude, knowledge, and skills; (b) the assessment was conducted by teachers, educational unit (school), and government and / or independent institution; (c) the implementation of the assessment at SCS' school refered to the minister of education regulation Number 66 year 2013 which explaines the Assessment Standard, the rules of Education Minister and Cultural Number 81A year 2013 that explaines the Curriculum Implementation and other rules relate to the assessment activities.

Learning Comprehansiveness

Learning comprehansiveness minimal for all competency base at knowledge and skill is 3,00 similar as B score. The minimal score for attitude is B. Student is declared graduated from school institution of SMA if completing the follow criterion: (1) finishing all the learning subjects; (2) $90 \%$ minimal of the subjects which is learned reach the Minimal Completing Criterion (MCC); (3) reach competency levels there are attittude competency (spiritual and social) minimal B or good level, knowledge and skill minimal reach MCC which is stated by the school institution for all the school subjects; (4) graduate from School Examination,; and (5) graduate from National Examination.

Grade Graduation Criterion

Based on the rule of Educational and Cultural Minister of Indonesia Republic Number 81A year 2013 about Curriculum 2013 Implementation was mention that the student at grade $\mathrm{X}$ is declared promote to the $\mathrm{XI}$ grade when reach the qualification creterion as follow: (a) the odd semester scores of all the subjects in the year ad to be completed at last two of the first months of the even semester; (b) there was no deficient score from MCC moore than 3 learning subjects; (c) the score of religion and personality subject (dicipline, tydiness, health, responsible, politness, self confident, competitive, social relationship, honesty, and pray implementation) minimal B or similar with good predicate; and (d) student's absent without permission in learning process of odd and even semester did not reach $10 \%$. The decision of grade graduation criterion and the MCC criterion are almost the same for the X, and XI grade, but XII grade was diferent, from the X grade to XI grade had special criterion, as well as in XI grade to XII grade also had special criterion, it was based on the completing consentrate school subjects taken.

Achievement Index Decision

Achievement Index was the average of combination from competency assessment of knowledge and skill. Semester Achievement Index was the learning achievement level of the student for all academic activity in a semester. At the three schools SMAN 1, SMAN 
3, and SMAN 1 Krian, was known the student in the second semester and subsequently is able to take a number of school subjects based on achievement index of the semester before with the term: (a) Achievement Index $<2.66$ is able to take 46 learning hour; (b) Achievement Index 2.67-3.33 maximal 54 learning hours; (c) Achievement Index 3.343.66 is able to take 62 learning hours; (d) Achievement Index > 3.66 maximal 70 learning hours; (e) moreover, attitude competency score at least B.

Remedial and Short Semester

The research result at the three schools of SMAN 1, SMAN 3, and SMAN 1 Krian Sidoarjo region, was found there was a remedial and short semester. Remedial was undertaken for: (a) the student had completed on certain competency yet; (b) executing time and remedial form activity had to be agreed each other by the sudent and teacher; and (c) the remedial score was not more than MCC. Remidial in semester credit system consisted of two ways there were retest and relearning of the subject. The student who had not finished at a subject because of failed in test, remidial was done by retest related with the middle semester or the last semester examination. Meanwhile, short semester activity could be done for improvement score of the student who has not finished to reach criterion of the subject until the last semester. Short semester: (a) just for repeating the subject which had not completed yet; (b) learning activity doing along learning process continuing and (c) it is just able to endure for student who hasn't reached MCC at certain subject.

\section{Graduation}

At the three shools of SMAN 1, SMAN 3, and SMAN 1 Krian Sidoarjo region was found that graduation criterion concept where student was declared pass from the school institution if: (a) finishing learning task minimal 260 learning hours, including minimal 144 learning hours at the A grouping subject and B general subject and minimal 116 laerning hour, $\mathrm{C}$ interest learning field, as well as reach achievement index minimal 2,66; (b) equiaring good score at attitude; and pass the school examination. The student graduation at Semester Credit System school, based on the criterion: had good attitude, passed school examinationfor all the school subjects, passed on National examination of some certain subjects, and some chosen subjects, as well as endure learning task of Semester Credit System minimal 130 credit.

\section{Student Mutation}

The research at the three shools of SMAN 1, SMAN 3, and SMAN 1 Krian was found that there were two kind of student mutation: first, learning subject choice mutation and second, change place mutation or move to othe school. Move to other learning subject will be served maximum 3 weeks after learning process started. Student who moved learning subject could be served when the class was not still overloaded maximum consisted of 32 students. Mutation of moving other school was minimized, and in emergency could be done as follow: (a) doing bridging course and ending with assessment dealing with pakage system curriculum structure for the student who moved to other school; and (b) doing bridging course and ending with assessment of learning subject and learning task of the three schools in the first and second semester. The students who passed bridging course could be accepted at the school need.

Boone and Kurtz (2007) explained that supervision and evaluation (controling) had mutual interrelationship with planning, because supervision had characterized as controlling, so 
all the activity running well suitable with the steps which was planned. Based on the some steps of supervision and evaluation, therefore grade graduation level criterion, remedial, and student mutation should have been done carefully, allow for the three aspects above as the main key of student's success as the indicator of the successful semester credit system implementation at schools.

\section{Conclusion}

Based on the research focuses, data explanation and research founding, as well as analyses and across sites discussion, the research result could be cocluded as follow:

First, The 2013 curriculum semester credit system planning at SMAN 1, SMAN 3, and SMAN 1 Krian, Sidoarjo region was conducted with reference of the national and regional decree of the 2013 curriculum implementation. Second, The organization of the 2013 curriculum semester credit semester at the state high schools (SMAN 1, SMAN 3, and SMAN 1 Krian) in Sidoarjo region, was done on the basis of the research which showed that the semester credit system was not far different from the package system. The differences falled on the several practices on the academic advisors. Third, the implementation of the semester credit system of the 2013 Curriculum at senior high schools (SMAN 1, SMAN 3, and SMAN 1 Krian), in Sidoarjo region showed that the implementation was done incrementally ranging from the acadeic year of 2013/2014 and 2015/2016. The new students orientation focused on the scialization of the semester credit system. Students could choose their own learning subjects. The selection for the stream of learning was done at the first semester considering the talents, motivation, potenciality, and academic performance of the students. Students of grade ten could choose 2 subject interets. They also could chose cross subjects of interests. Grade eleven could only choose one subject interets. To enhance the quality of learning moving classes were done. Fourth, the supervision and evaluation of the semester credit system of the 2013 curriculum at SMA Negeri (SMAN 1, SMAN 3, and SMAN 1 Krian) in Sidoarjo region was aimed at measuring the students achieveent in konwledge psychomotor, and attitude domains. The criteria of the mastery learning was considered 3 or B. The Acievement Indext decision was done by considering all academic activities and the minimum requitements of learning times and assignments

\section{Suggestion}

Based on the conclusion above, there were some suggestions for the research as follow:

The Headmaster

The head master has been expected to get the few of theory, practice, and wishdom that in implementation of SCS Curriculum 2013, there are many troubles and inadequacy especially in managing teaching hours of schedule in SCS hasn't been admited like independent learning, and learning task in Dapodik and learning mechanism of comprehend interst subject, so it needs adaptated and completed.

Teachers and administrators

Teachers and administrators have been expecter to get aditional of information and knowledge of SCS effectivity at school. The readiness of education resources mangerially, pedagogic, professional, and social as the main requirement of implementing SCS optimally. So, the teachers and administrators are claimed to comprehend and master of SCS regulations or rules, socialization system, implementation, inspecting and evaluating 
of SCS implementation at school. Unless doing that, there'll be default or unsuccessful to realize the obligation of effective education, teachers and administrators professionalism.

The Department of Education of Sidoarjo region

It was expected that the Department of education of Sidoarjo region is able to review the education competency complecity, there were managerial, pedagogic, professional, personality, and social competency, and also the instruments need for implementing the semester credit system of the 2013 Curriculum perfectly, especially arranging the teachers' teaching hours in learning schedule and learning mechanism of comprehend interest subject

The BPSDMPK and PMP Ministery of Education and Culture of Indonesia Republic

It was expected that the BPSDMPK and PMP Ministry of education and Culture of Indonesia Republic is able to consider and issues some wishdoms or the steps related to recover some the weakness found related to the semester credit system of the 2013 Curriculum management implementation, especially in teaching hour for the teacher and learning interest subject comprehention mechanism. In order to get maximal score, it needs trainning for teachers and administrator by BPSDMPK and PMP for SCS management implementation, and also arrange local and distric characteristic.

The P4TK and LPMP

It has been suggested that the P4TK and LPMP have to prepare training and coaching related to completing and teacher and administrator's readiness.

The next reseacher

It has been expected that this research is sueful for other reseaerchers use as reference of the next reserach related to the effectiveness semester credit system of the 2013 Curriculum, especially related to completness of the rules, socialization, implementation, evaluation, and follow up the semester credit system implementation as one of the research source.

\section{Biblography}

Arifin, I. 2010. Kepemimpinan Kyai dalam Sistem Pengajaran Kitab-Kitab Islam Klasik: Studi Kasus Pondok Pesantren Tebu Ireng. Unpublished thesis. Malang: Program Pasca Sarjana Institut Keguruan dan Ilmu Pendidikan.

Bafadal, I. 2004. Proses Perubahan Pada Sekolah Dasar: Studi Multi Situs Tiga Sekolah Dasar di Sumekar. Unpublished desertation. Malang: PPS IKIP Malang. Basic law of Indonesia Republic Year 1945

Bogdan, R.C dan Biklen, S.K. 2007. Qualitative Research for Education: An Introduction to Theory and Methods. London: Allyn and Bacon, Inc.

Boone, L. E. dan Kurtz, D. L. 2007. Principles of Management 2th Edition. New York: Random House, Inc.

BSNP. 2010. Panduan Penyelenggaraan Sistem Kredit Semester untuk Sekolah Menengah Pertama/Madrasah Tsanawiyah dan Sekolah Menengah Atas/Madrasah Aliyah. Jakarta: Badan Standar Nasional Pendidikan. Budiman, B. 2013. Penerapan Sistem SKS Perlu Kesiapan Pihak Sekolah.Online: http://www.antarasumsel.com/berita/275384/, accessed at 26 Februari 2014.

Creswell, J. W. 2004. Research Design: Qualitative and Quantitative 
Approaches. Thousand Oaks: SAGE Publications.

Government Rule Number 19 Year 2005 about Education National Standard and changes with Nomor 32 Year 2013 abut the changes of Government Rule Number 19 Year 2005 about Educational National Standard.

Handoko, T. 2012. Manajemen: Edisi 2. Yogyakarta: BPFE Yogyakarta.

Hoy, W. K. dan Miskel, C. G. 2005. Educational Administration: Theory, Research, and Practice 7th Edition. New York: McGray Hill.

Imron, A. 2011. Proses Manajemen Pendidikan. Powerpoint: Presented on $\backslash$ Prepasca Magister Activity Pascasarjana Program Studi Manajemen Pendidikan Angkatan 2011. Tidak diterbitkan.

Kemendikbud. 2014. Manajemen Implementasi Kurikulum 2013: Bahan Ajar Implementasi Kurikulum 2013 untuk Kepala Sekolah. Jakarta: Pusat \ Pengembangan Tenaga Kependidikan, Badan Pengembangan Sumber Daya Manusia Pendidikan dan Kebudayaan dan Penjaminan Mutu Pendidikan, Kementerian Pendidikan dan Kebudayaan.

Kementerian Pendidikan dan Kebudayaan. 2013. Materi Pelatihan Implementasi Kurikulum 2013 SMA/MA dan SMK/MAK: Bahasa Indonesia 2013.Jakarta: Kemendikbud.

Kementerian Pendidikan dan Kebudayaan. 2010. Panduan Sistem Kredit Semester BSNP, April 2010. Kementerian Pendidikan dan Kebudayaan. Kementerian Pendidikan dan Kebudayaan. 2013. Penilaian Autentik Pada Proses dan Hasil Belajar 2013. Hand out 2.3.1 Pelatihan Instruktur Nasional Implementasi Kurikulum 2013. Jakarta: Kemendikbud.

Law of Indonesian Republic Number 17 Year 2005 about Rencana

Pembangunan Jangka Panjang Nasional, beserta segala ketentuan yang dituangkan Rencana Pembangunan Jangka Menengah Nasional.

Law of Indonesi Republic Number 20 Year 2003 about Nastional Education System.

Lofland, J. dan Lyn, L. 2004. Analyzing Social Setting: A Guide to Qualitive Observation and Analysis: 2nd Edition. Belmont CA: Wadsworth.

Miles, M.B dan Huberman, A.M. 1992. Analisis Data Kualitatif: Buku Sumber Tentang Metode-Metode Baru. Translated by Tjetjep R.R. Jakarta: UI Press. Moleong, L. J. 2011. Metodologi Penelitian Kualitatif. Bandung: Remaja Rosda Karya.

Somantri, G. R. 2007. Memahami Metode Kualitatif: Jurnal Makara, Sosial Humaniora, Vol. 9, No. 2, Desember 2005: 57-65. Online: http://journal.ui.ac.id, accessed at 26 April 2012.

The law of Bupati Sidoarjo Number 188/410/404.1.3.2/2013 tentang Penetapan Satuan Pendidikan Penyelenggara Sistem Kredit Semester dan Peraturan Bupati tentang Perubahan Atas Peraturan Bupati Sidoarjo No. 21 Tahun 2015 tentang Pedoman Pelaksanaan Penerimaan Peserta Didik Baru Satuan Pendidikan Sekolah Menengah Pertama dan Sekolah Menengah Atas Penyelenggara Sistem Kredit Semester di Lingkungan Kabupaten Sidoarjo di Sidoarjo.

The rule of Bupati Sidoarjo Number: 63 Year 2011 about Education Standar of Read and Write Al-Quran.

The rule of Educational and Cultural Minister Indonesia Republic Number 81A \Tahun 2013 about Curriculum 2013 Implementation.

The rule of Educational and Cultural Minister Indonesia Republic Number 69 Tahun 2013 about Frame Base and Curriculum Structure of SMA/MA. 
The rule of Educational and Cultural Minister Indonesia Republic Number 54 Year 2013 about Graduation Competency Standard.

The rule of Educational and Cultural Minister Indonesia Republic Number 64 Year 2013 about Content Standard.

The rule of Educational and Cultural Minister Indonesia Republic Number 65 Year 2013 about Process Standard.

The rule of Educational and Cultural Minister Indonesia Republic Number 66 Year 2013 about Assessment Standard.

The rule of Educational and Cultural Minister Indonesia Republic Number 69 Year 2013 about Competency Base and Curriculum Structure of SMA/MA.

The rule of Educational and Cultural Minister Indonesia Republic Number 158 Year 2014 about Semmester Credit System.

Terry, N. 2007. Focus On The Future A Career Development Curricullum for Secondary School Student. New York: IDEBATE Press Book.

Ulfatin, N. 2004. Hambatan Kesempatan Guru Wanita Menjadi Kepala Sekolah Ditinjau dari Segi Sosial Kultural. Unpublished Desertation. Malang: Pasca

Sarjana Universitas Negeri Malang.

Usman, H. 2010. Manajemen Teori, Praktik, dan Riset Pendidikan. Yogyakarta: Bumi Aksara.

Wiyono, B.B. 2007. Metodologi Penelitian: Pendekatan Kuantitatif, Kualitatif, dan Action Research. Malang: Fakultas Ilmu Pendidikan Universitas Negeri Malang.

Wulan, A.N. 2013. Penilaian Proses dan Hasil Belajar Kurikulum 2013. Bahan Paparan: Disajikan dalam Workshop Pembahasan dan Finalisasi Naskah

Pendukung Pembelajaran, Direktorat Pembinaan SMA, Kemendikbud, 22 Agustus, 2013. Jakarta: Kemendikbud. 